\title{
Modeling and Simulation of DC-DC Converters for Fuel Cell System
}

\author{
S. Kavyapriya, R. Krishna Kumar
}

\begin{abstract}
This paper deals with the modeling and simulation of suitable DC-DC converters for Fuel cell system. In the field of renewable energies, power electronics and fuel cell technologies play an important role. As the fuel cells become the main power source for portable applications, demand for fuel cells will increase. A highly efficient converter is an essential requirement in this application and a core parameter of the device as a whole. Therefore, a high efficient converter has to be designed for fuel cell system as the output voltage of fuel cell is low. In this paper, various DC-DC converters such as Boost converter, SEPIC, LUO converter and ZETA converter with fuel cell as an input source are designed and the same is simulated using MATLAB. Total Harmonic Distortion analysis of all the DC-DC converters is carried out and the suitable converter for fuel cell application is selected based on the low Total Harmonic Distortion value.
\end{abstract}

Keywords: Fuel cell, Boost converter, SEPIC, LUO converter, ZETA converter, Total Harmonic Distortion

\section{INTRODUCTION}

Compared with traditional fossil-fuel systems, renewable energy systems deliver environmental and economic advantages in energy production. Fuel cells are the most common among all forms of green energy applications since they can provide a continuous supply of power throughout all seasons as long as fuel is supplied. Certain types of green energy such as solar or wind energy, by contrast, depend on the weather [1], [2]. At present the fuel cell (FC) stimulates so much new interest at the industrial level as at the research level. Industrialists from various sectors (electronics, cell phones, automobiles, power generation, heating, etc.,) are investing in the production of this high-density technology with low harmful gas emissions [3], [4]. Fuel Cells are electrochemical devices which directly convert the fuel's chemical energy to electricity. There are various types of FCs, distinguished by their electrolytes. The polymer electrolyte membrane FC (PEMFC) is one of the most promising to be used for stationary or transported applications due to its relatively small size, simple design, lightweight, and low operating temperature [5], [6]. Membranes FCs are composed of two compartments of electrodes separated by a polymer electrolyte membrane to prevent the movement of gas and electrons. The two electrodes are placed on the side of the membrane, creating the individual cell's membrane - electrode assembly (MEA).

Revised Manuscript Received on February 05, 2020.

* Correspondence Author

S. Kavyapriya, Department of Electrical and Electronics Engineering, PSG College of Technology, Coimbatore, India.

Mr. R. Krishna Kumar, Department of EEE, PSG College of Technology, Coimbatore, India.

smoussa@cud.ac.ae

(C) The Authors. Published by Blue Eyes Intelligence Engineering and Sciences Publication (BEIESP). This is an open access article under the CC BY-NC-ND license (http://creativecommons.org/licenses/by-nc-nd/4.0/)
Protons formed by hydrogen oxidation migrate through the membrane, which most often exhibits a high affinity to water, to the cathode with water, and participate in the reduction of oxygen into water. The difference of the available voltage with the supplied current

Density can be defined by the FCs. Typical cell voltage at $0.4-0.8 \mathrm{~A} / \mathrm{cm} 2$ is in the order of $0.6 \mathrm{~V}$. Higher voltages can be achieved in FC systems by connecting a number of individual Cells in series that form a FC stack. Nonetheless, the renewable energy supplied by fuel cells has a characteristic of low- voltage performance, and hence a highstep DC-DC converter is needed for any future practical applications.

\section{DC-DC CONVERTERS}

There are different types of power electronic converters that are often used in electrical power system applications such as regulated power supply, DC power supply and so on. The converters of power electronics can be categorized as AC to DC converters, DC to AC converters, AC to AC converters, DC to DC converters, and so on.

A DC-DC converter is a power electronic device that accepts a voltage from DC input and also provides a DC output voltage. DC to DC converter output voltage may be higher than the input voltage, or vice versa. The output voltages of the converter are used to match the power supply required for the loads. A switch in the basic DC to DC converter circuit can be used to control the connection and disconnection of the power supply to the load. DC to DC converter circuits consist of a transistor or diode switch, energy storage devices such as inductors or capacitors and these converters are typically used as linear voltage regulators or switched mode voltage regulators. DC to DC converters also provide DC regulated power supply and constant DC power supply to the load.

The DC-DC converters are used for power conditioning purposes in fuel cell systems. The DC-DC converters mentioned in this paper are used not only in fuel cell systems but in everyday applications as well. This paper describes the four DC-DC converters namely:

- Boost converter

- SEPIC

- LUO converter

- ZETA converter 


\section{Modeling and Simulation of DC-DC Converters for Fuel Cell System}

\section{A. Boost Converter}

A Boost converter is a DC to DC converter in which the output voltage is higher than the voltage reference. It is referred to as a step-up converter. Boost converter's main operating theory is that the inductor in the input circuit resists sudden changes in input current. The inductor stores energy in the form of magnetic energy when switch is on, and discharges it when switch is closed.

The capacitor in the output circuit is assumed to be large enough that the RC circuit time constant is high in the output level [7]. The general configuration of boost converter is shown in Fig. 1.

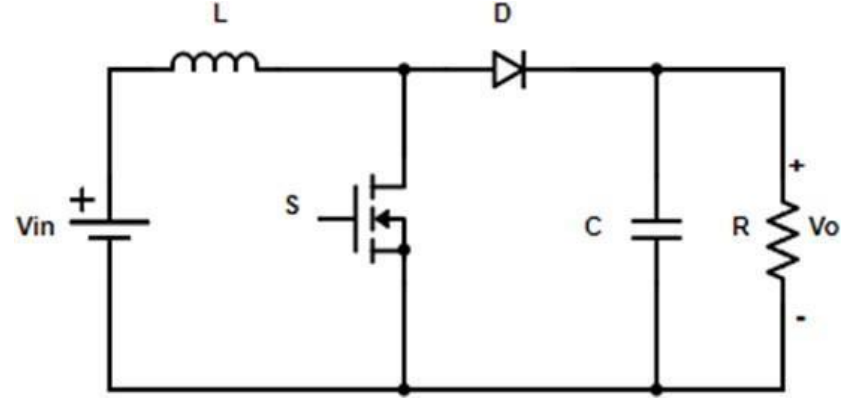

Fig. 1. Circuit diagram of Boost Converter

\section{MODE 1: When the switch is ON}

The diode will be open circuited as the n side of the diode is at higher voltage compared to the $\mathrm{p}$ side. The inductor charges and the inductor current increases during this state.

\section{MODE 2: When the switch is OFF}

The switch is made to open and the diode will be shortcircuited during the OFF time, making it the only way for inductor current to flow through the' D' fly-back diode and the parallel capacitor and load combination. This allows the capacitor to transfer the energy it acquired during the $\mathrm{ON}$ phase.

\section{Design Calculation}

The design equations for boost converter are given in equations (1), (2) and (3) and the parameters are tabulated in Table-I.

1. Calculation of Duty Cycle: $D=1-\frac{V_{\text {in }}}{V_{o}}$

2. Value of Inductor

$$
: \mathrm{L}=\frac{\mathrm{V}_{\text {in }} \mathrm{D}}{\mathrm{f}_{\mathrm{s}} \Delta \mathrm{I}}
$$

3. Value of Capacitor

$$
: C=\frac{I_{0} D}{f_{s} \Delta V}
$$

Where $\mathrm{V}_{\text {in }}$ - Input Voltage

$$
\begin{aligned}
& \mathrm{V}_{\mathrm{o}} \text { - Output Voltage } \\
& \mathrm{f}_{\mathrm{s}} \text { - Switching frequency } \\
& \Delta \mathrm{I} \text { - Inductor ripple current } \\
& \Delta \mathrm{V} \text { - Capacitor ripple voltage } \\
& \mathrm{R} \text { - Load resistance }
\end{aligned}
$$

Table- I: Design parameters of Boost Converter

\begin{tabular}{|l|c|}
\hline \multicolumn{1}{|c|}{ PARAMETERS } & VALUE \\
\hline Input Voltage & $12 \mathrm{~V}$ \\
\hline Output Voltage & $48 \mathrm{~V}$ \\
\hline Duty Cycle & $75 \%$ \\
\hline Switching frequency & $50 \mathrm{KHz}$ \\
\hline
\end{tabular}

When the switch is turned ON, the inductor L1 is charged by the supply voltage and the inductor L2 is charged by the capacitor C1. The diode is reverse biased and hence the output is maintained by the capacitor C2.

\section{MODE 2: When the switch is OFF}

When the switch is turned OFF, the diode will be forward biased and the inductors output through the diode to the load and the capacitors C1 and C2 are charged.

\section{Design Calculation} (4),

(5) and (6) and the parameters are tabulated in Table-II.

1. Calculation of Duty Cycle $: D=\frac{V_{\text {in }}}{V_{o}+V_{\text {in }}}$

2. Value of Inductor $: \mathrm{L}_{1}=\frac{\mathrm{V}_{\mathrm{in}} \mathrm{D}}{\mathrm{f}_{\mathrm{s}} \Delta \mathrm{I}} ; \mathrm{L}_{2}=\frac{\mathrm{V}_{\mathrm{in}}(1-\mathrm{D})}{\mathrm{f}_{\mathrm{s}} \Delta \mathrm{I}}$

3. Value of Capacitor : $\mathrm{C}_{1}=\frac{\mathrm{I}_{\mathrm{o}} \mathrm{D}}{\mathrm{f}_{\mathrm{s}} \Delta \mathrm{V}} ; \mathrm{C}_{2}=\frac{\mathrm{I}_{\mathrm{o}} \mathrm{D}}{\mathrm{f}_{\mathrm{s}} \Delta \mathrm{V}}$

Where $\mathrm{V}_{\text {in }}$ - Input Voltage

$\mathrm{V}_{\mathrm{o}}$ - Output Voltage

$\mathrm{f}_{\mathrm{s}}$ - Switching frequency

$\Delta \mathrm{I}$ - Inductor ripple current

$\Delta \mathrm{V}$ - Capacitor ripple voltage

$\mathrm{R}$ - Load resistance 
Table-II: Design parameters of SEPIC

\begin{tabular}{|l|c|}
\hline \multicolumn{1}{|c|}{ PARAMETERS } & VALUE \\
\hline Input Voltage & $12 \mathrm{~V}$ \\
\hline Output Voltage & $48 \mathrm{~V}$ \\
\hline Duty Cycle & $80 \%$ \\
\hline Switching frequency & $50 \mathrm{KHz}$ \\
\hline Inductor & $1.33 \mathrm{mH}$ \\
\hline Capacitor C1 & $384 \mu \mathrm{F}$ \\
\hline Capacitor C2 & $768 \mu \mathrm{F}$ \\
\hline Resistive load & $100 \Omega$ \\
\hline
\end{tabular}

\section{LUO Converter}

LUO converters are a series of new DC-DC step-up (boost) conversion circuits. Luo-Converters possess interesting features such as simple circuit structure, high efficiency and near- zero output voltage and current ripples. The distinction between Luo and other traditional DC-DC converters is that the voltage is improved with the Luo converters in a geometric progression [9]. The general configuration of LUO converter is shown in Fig. 3.

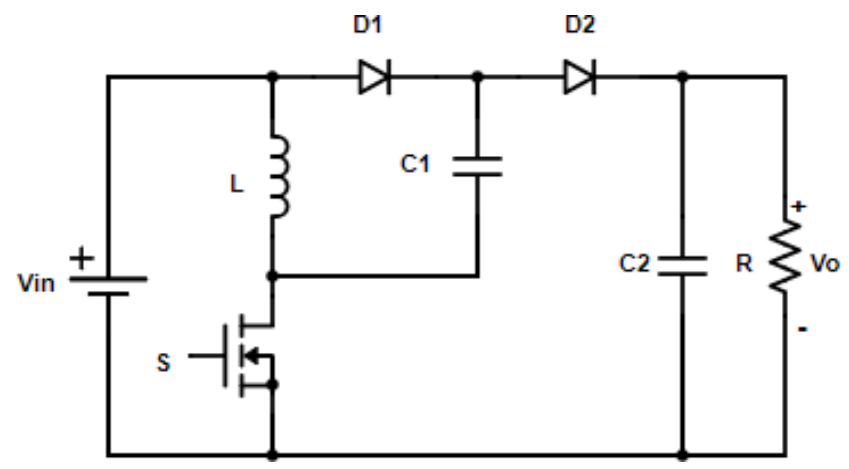

Fig. 3. Circuit diagram of LUO Converter

\section{MODE 1: When the switch is ON}

This converter works in continuous conduction mode, and the output terminal voltage is positive. The input voltage is transmitted directly to the inductor $\mathrm{L}$ and capacitor $\mathrm{C} 1$, both of which are charged when the switch is in ON state. The load is supplied by the capacitor C2 and the current through the inductor rises. The diode D1 is used for freewheeling purpose.

\section{MODE 2: When the switch is OFF}

When the switch is turned off, the inductor current decreases and the capacitor C2 gets charged. The diode D2 is used for freewheeling purpose.

\section{Design Calculation}

The design equations for LUO converter are given in equations (7), (8) and (9) and the parameters are tabulated in the Table-III.

1. Calculation of Duty Cycle: $\mathrm{D}=\frac{\mathrm{V}_{\mathrm{o}}-2 \mathrm{~V}_{\text {in }}}{\mathrm{V}_{\mathrm{o}}-\mathrm{V}_{\text {in }}}$ (7)

2. Value of Inductor: $L=\frac{V_{\text {in }} D}{f_{s} \Delta I}$

3. Value of Capacitor:

$$
\mathrm{C}_{1}=\mathrm{C}_{2}=\frac{\mathrm{V}_{\mathrm{o}} \mathrm{D}}{\mathrm{f}_{\mathrm{s}} \mathrm{R} \Delta \mathrm{V}}
$$

Where $\mathrm{V}_{\text {in }}$ - Input Voltage

$\mathrm{V}_{\mathrm{o}}$ - Output Voltage

$\mathrm{f}_{\mathrm{s}}$ - Switching frequency

$\Delta \mathrm{I}$ - Inductor ripple current

$\Delta \mathrm{V}$ - Capacitor ripple voltage

$\mathrm{R}$ - Load resistance

Table-III: Design parameters of LUO Converter

\begin{tabular}{|l|c|}
\hline \multicolumn{1}{|c|}{ PARAMETERS } & VALUE \\
\hline Input Voltage & $12 \mathrm{~V}$ \\
\hline Output Voltage & $48 \mathrm{~V}$ \\
\hline Duty Cycle & $66.67 \%$ \\
\hline Switching frequency & $50 \mathrm{KHz}$ \\
\hline Inductor & $3.335 \mathrm{mH}$ \\
\hline Capacitor (C1=C2) & $133.4 \mu \mathrm{F}$ \\
\hline Resistive load & $100 \Omega$ \\
\hline
\end{tabular}

\section{ZETA Converter}

A ZETA converter is a fourth order Nonlinear system being that, with regard to energy input, it can be seen as buck- boost-buck converter and with regard to the output, it can be seen as boost-buck-boost converter. The general configuration of ZETA converter is shown in Fig. 4.

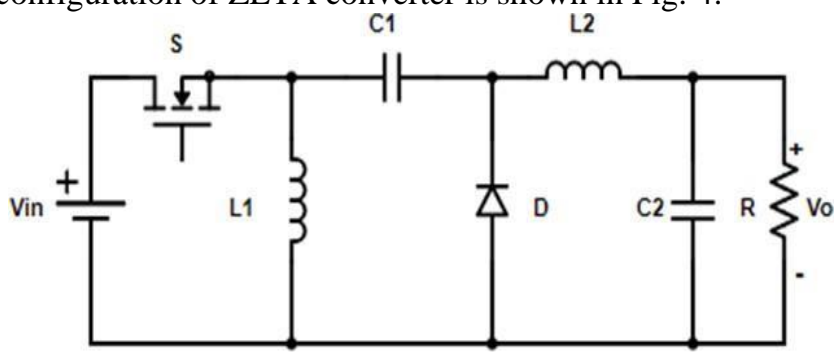

Fig. 4. Circuit diagram of ZETA Converter

\section{MODE 1: When the switch is ON}

The first mode is obtained when the switch is ON (closed) and instantaneously, the diode D is OFF. During this period, the current through the inductor L1 and L2 are drawn from the voltage source Vin. This mode is the charging mode.

\section{MODE 2: When the switch is OFF}

The second mode of operation starts when the switch is OFF and the diode D is ON position. This stage or mode of operation is known as the discharging mode since all the energy stored in L2 is now transferred to the load R.

\section{Design Calculation}

The design equations for ZETA converter are given in equations (10), (11) and (12) and the parameters are tabulated in the Table-IV.

1. Calculation of Duty Cycle: $\mathrm{D}=\frac{\mathrm{v}_{\mathrm{o}}}{\mathrm{v}_{\mathrm{o}}+\mathrm{V}_{\mathrm{in}}}$ (10)

2. Value of Inductor: $L=\frac{V_{\text {in }} D}{f_{s} \Delta I}$

3. Value of Capacitor: $\mathrm{C}_{1}=\frac{\mathrm{V}_{\mathrm{o}} \mathrm{D}}{\mathrm{f}_{\mathrm{s}} \mathrm{R} \Delta \mathrm{V}} ; \mathrm{C}_{2}=\frac{\mathrm{V}_{\mathrm{o}}(1-\mathrm{D})}{8 \mathrm{f}_{\mathrm{s}} \Delta \mathrm{V}}$ 
Modeling and Simulation of DC-DC Converters for Fuel Cell System

Table-IV: Design parameters of ZETA Converter

\begin{tabular}{|l|c|}
\hline \multicolumn{1}{|c|}{ PARAMETERS } & VALUE \\
\hline Input Voltage & $12 \mathrm{~V}$ \\
\hline Output Voltage & $48 \mathrm{~V}$ \\
\hline Duty cycle & $80 \%$ \\
\hline Switching frequency & $50 \mathrm{KHz}$ \\
\hline Inductor (L1=L2) & $0.16 \mathrm{mH}$ \\
\hline Capacitor (C1) & $16 \mu \mathrm{F}$ \\
\hline Capacitor (C2) & $312.5 \mathrm{mF}$ \\
\hline Resistive load & $100 \Omega$ \\
\hline
\end{tabular}

\section{SIMULATION OF CONVERTERS WITH FUEL CELL}

The Simulink model of DC-DC converters like Boost converter, SEPIC, LUO converter and ZETA converter with Fuel cell input are shown below.

\section{A. Fuel Cell Model}

The Simulink block of fuel cell which is designed for 12 $\mathrm{V}$ is shown in Fig. 5.

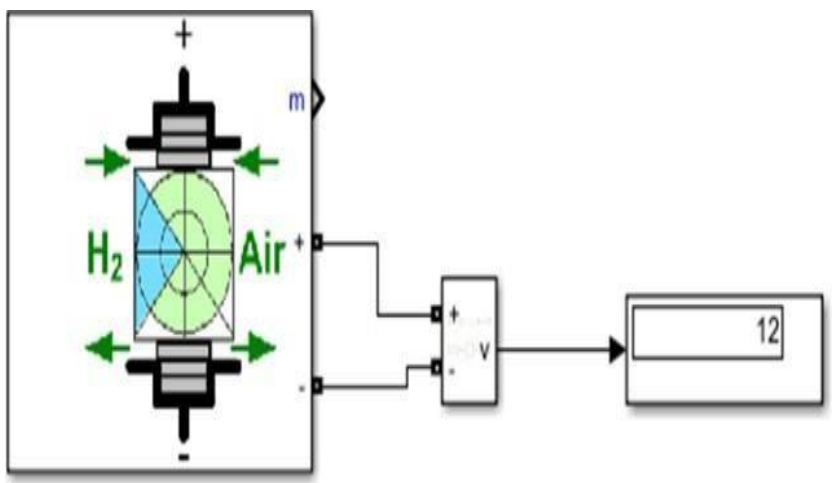

Fig. 5. Fuel cell simulation model

\section{B. Simulation of Boost Converter}

The Matlab Simulink model of Boost converter is shown in Fig. 6.

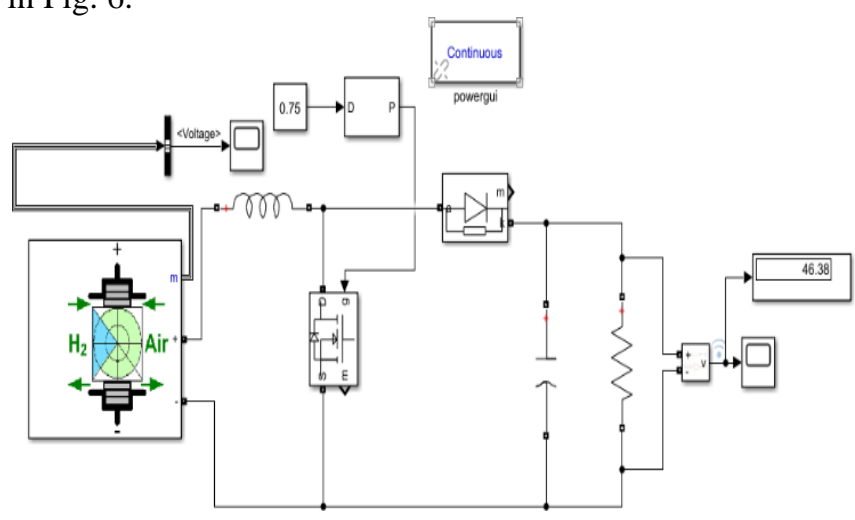

Fig. 6. Simulation model of Boost converter with Fuel cell

The output voltage and THD waveforms of Boost converter are shown in Fig. 7 and Fig. 8 respectively.

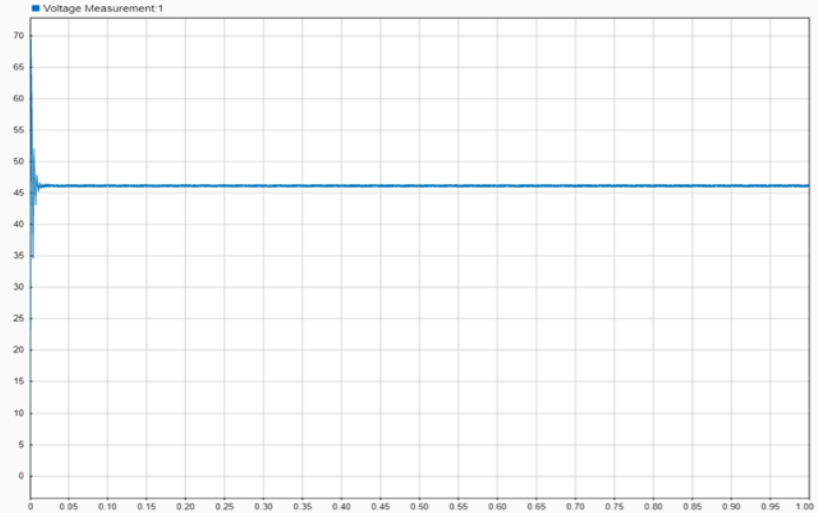

Fig. 7. Waveform of Boost converter's output voltage

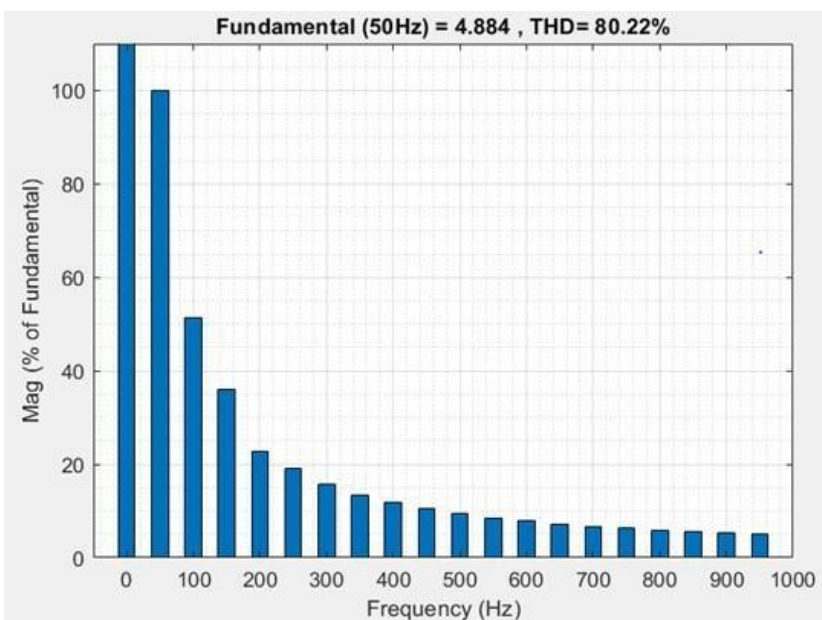

Fig. 8. Voltage THD analysis waveform of Boost converter

\section{Simulation of SEPIC}

The Matlab Simulink model of SEPIC is shown in Fig. 9.

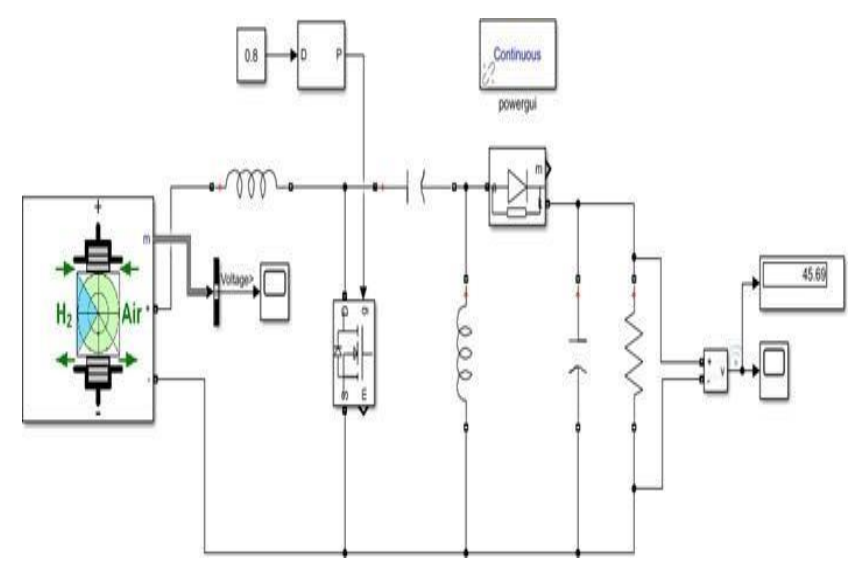

Fig. 9. Simulation model of SEPIC with Fuel cell

The output voltage and THD waveforms of SEPIC are shown in Fig. 10 and Fig. 11 respectively. 


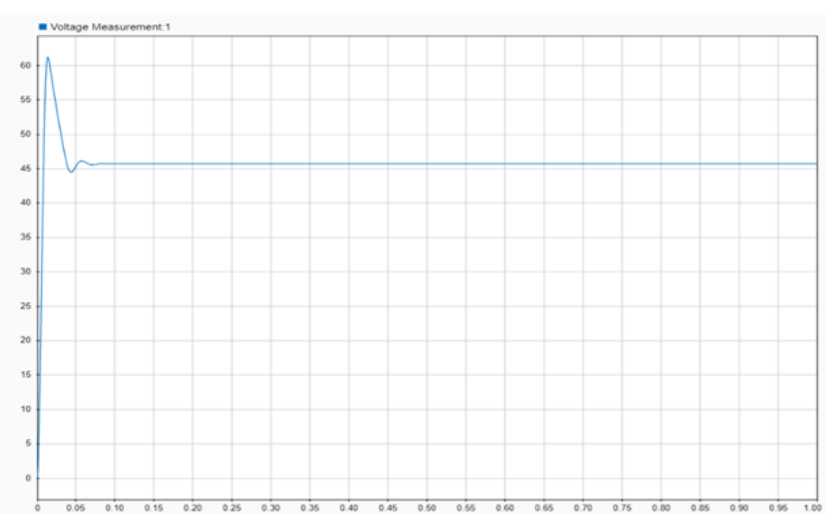

Fig. 10. Waveform of SEPIC's output voltage

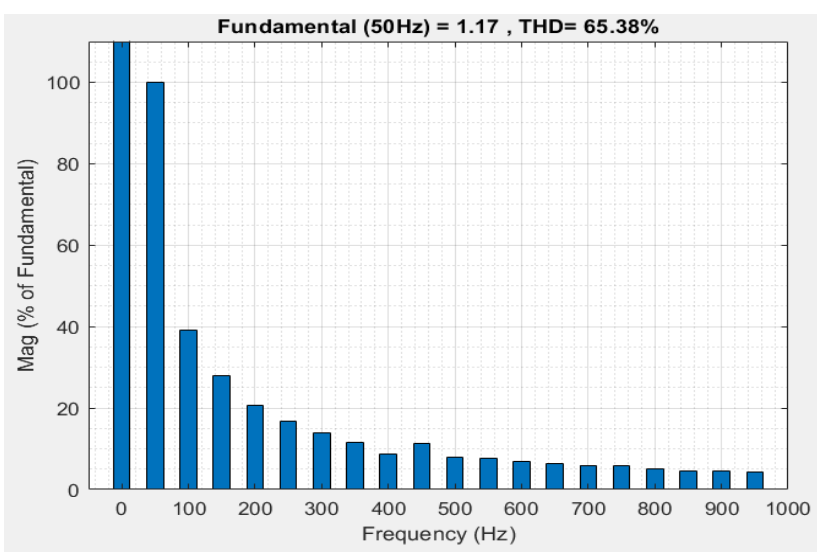

Fig. 11. Voltage THD analysis waveform of SEPIC

\section{Simulation of LUO Converter}

The Matlab Simulink model of LUO Converter is shown in Fig. 12.

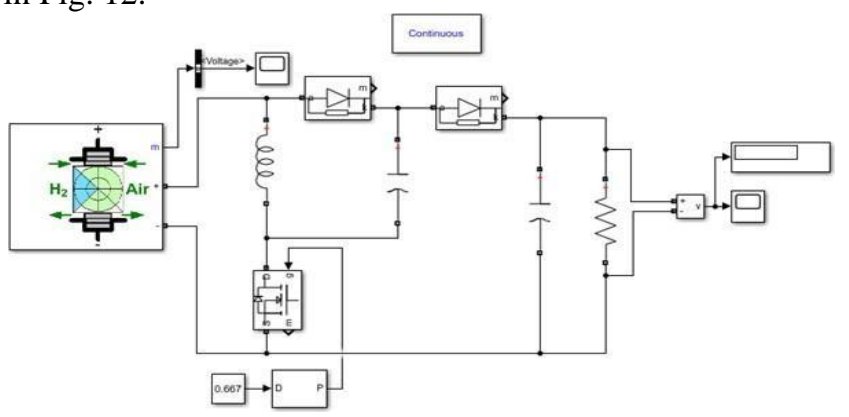

Fig. 12. Simulation model of LUO converter with Fuel cell

The output voltage and THD waveforms of LUO converter are shown in Fig. 13 and Fig. 14 respectively.

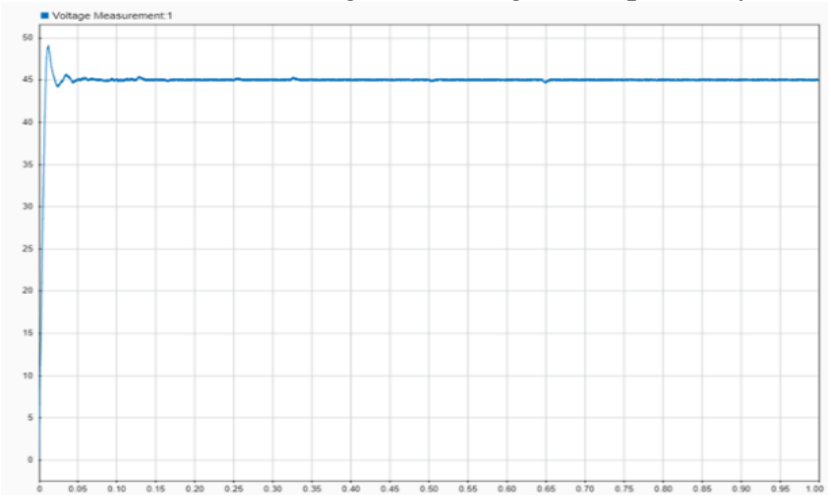

Fig. 13. Waveform of LUO converter's output voltage
Published By:

Blue Eyes Intelligence Engineering

\& Sciences Publication

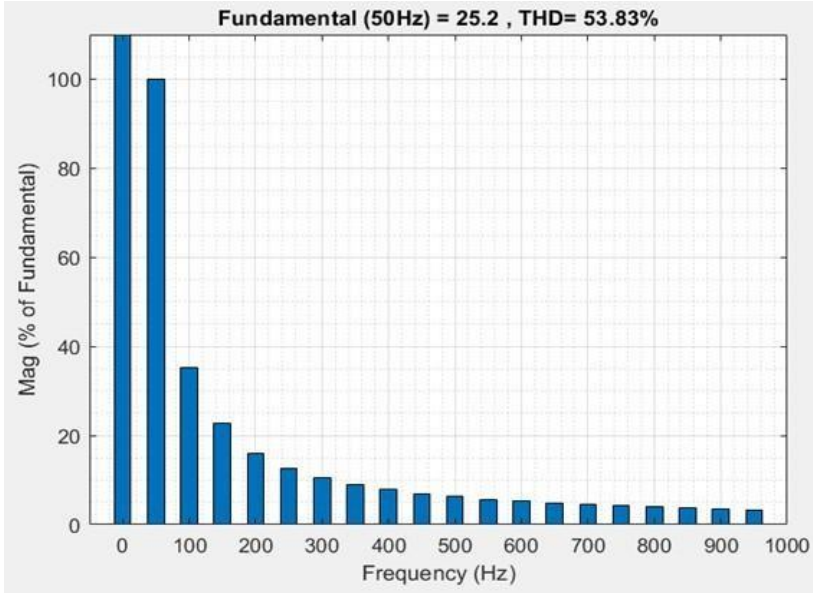

Fig. 14. Voltage THD analysis waveform of LUO converter

\section{E. Simulation of ZETA Converter}

The Matlab Simulink model of ZETA Converter is shown in Fig. 15.

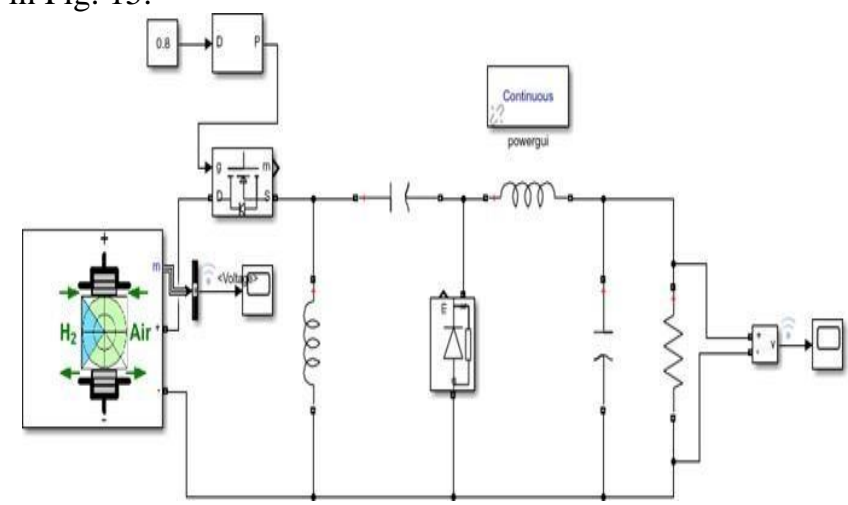

Fig. 15. Simulation model of ZETA converter with Fuel cell

The output voltage and THD waveforms of ZETA converter are shown in Fig. 16 and Fig.17 respectively.

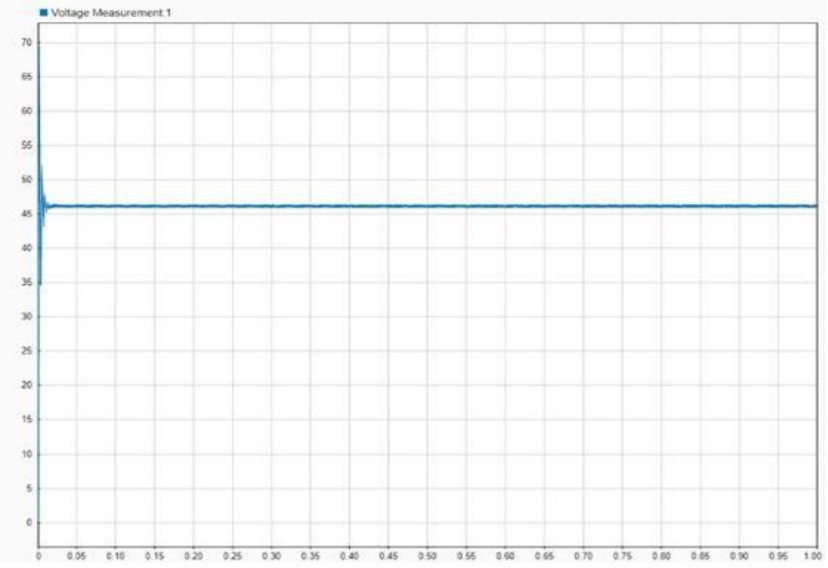

Fig. 16. Waveform of Zeta converter's output voltage

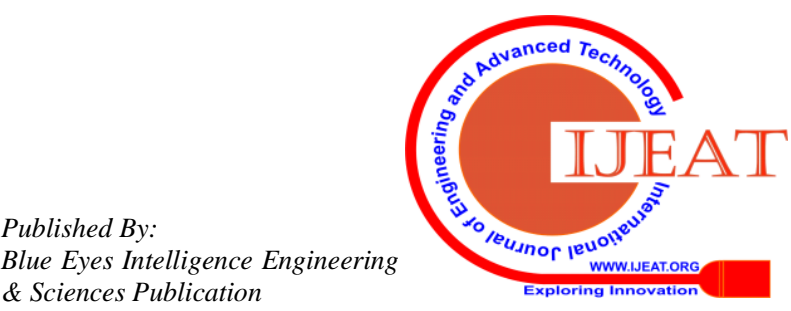




\section{Modeling and Simulation of DC-DC Converters for Fuel Cell System}

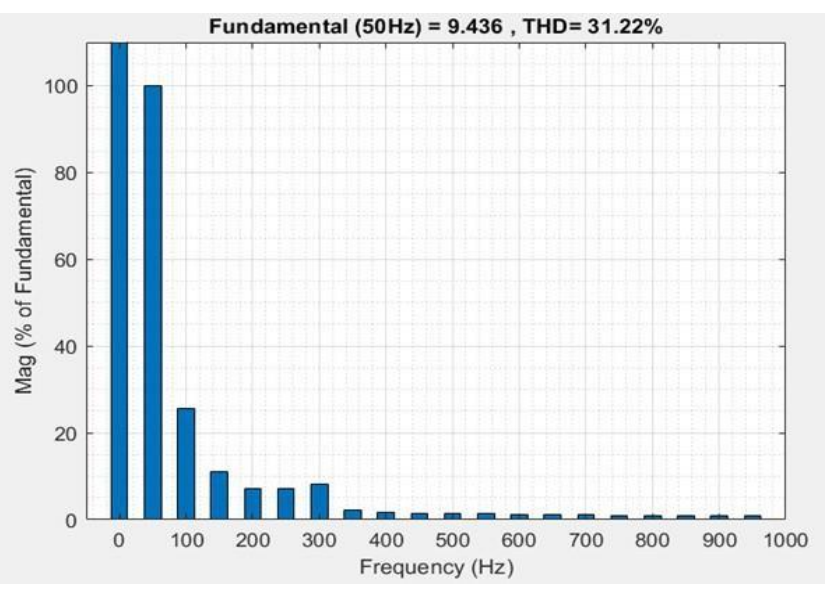

Fig. 17. Voltage THD analysis waveform of ZETA converter

\section{RESULTS AND DISCUSSION}

The THD analysis of Boost converter, SEPIC, LUO converter and ZETA converter with fuel cell as an input source is carried out using MATLAB and the values are listed in the Table- $\mathrm{V}$.

Table-V: THD analysis of converters

\begin{tabular}{|l|c|}
\hline CONVERTER & THD VALUE \\
\hline Boost converter & $80.22 \%$ \\
\hline SEPIC & $65.38 \%$ \\
\hline LUO converter & $53.83 \%$ \\
\hline ZETA converter & $31.22 \%$ \\
\hline
\end{tabular}

From the Table-V, it can be inferred that the THD value of ZETA converter is less than Boost, SEPIC and LUO converters. Low THD value of ZETA converter implies that the efficiency of the converter will be improved than the other converters.

\section{CONCLUSION}

The design and simulation of various converters such as boost converter, SEPIC, LUO converter and ZETA converter with fuel cell as an input source are carried out using MATLAB simulink. The design parameters of each converter are tabulated and the simulated output voltage waveforms are shown. In addition to this THD analysis of each converter is performed. It is concluded that ZETA converter exhibits better performance than Boost converter, SEPIC and LUO converter with respect to THD. ZETA converter performance can still be increased by adding suitable filters.

\section{REFERENCES}

1. F. Blaabjerg, Z. Chen, and S. B. Kjaer, "Power electronics as efficient interface in dispersed power generation systems," IEEE Transactions on Power Electronics, vol. 19, no. 5, pp. 1184-1194, 2004.

2. J. M. Carrasco, L. G. Franquelo, J. T. Bialasiewicz et al., "Power electronic systems for the grid integration of renewable energy sources: a survey," IEEE Transactions on Industrial Electronic, vol. 53, no. 4, pp. 1002-1016, 2006.

3. M. Yamaguchi, T. Saito, M. Izumitani, S. Sugita, and Y. Tsutsumi, "Analysis of control characteristics using fuel cell plant simulator," IEEE Trans. Ind. Electron., vol. 31, no. 5, pp. 378-386, Oct. 1990.

4. K. Jin, X. Ruan, M. Yang, and M. Xu, "A hybrid fuel cell power system," IEEE Trans. Ind. Electron., vol. 56, no. 4, pp. 1212-1222,
Apr. 2009.

5. J. Lee, J. Jo, S. Choi, and S. B. Han, "A 10-kW SOFC low voltage battery hybrid power conditioning system for residential use," IEEE Trans. Energy Convers., vol. 21, no. 2, pp. 575-585, Jun. 2006.

6. Y. T. Seo, D. J. Seo, J. H. Jeong, and W. L. Yoon, "Development of compact fuel processor for $2 \mathrm{~kW}$ class residential PEMFCs," J. Power Sources, vol. 163, no. 1, pp. 119-124, Dec. 2006

7. Mohammed Abdulla Abdulsada, "Analysis, Design and Simulation of $12 \mathrm{v} / 24 \mathrm{v}$ Boost Switching Converter," International Journal of Engineering Sciences \& Research Technology, vol. 3, no. 6, pp. 836846, June 2014.

8. E.Mamarelis et al., "Design of a Sliding-Mode- Controlled SEPIC for PV MPPT Applications”, IEEE Trans. Ind. Electron., vol. 61, no. 7, pp. 3387-3398, Jul. 2014.

9. S. Nimimol, Dr. V. Gopalakrishnan and Immanuel John Samuel, "Comparative analysis of SEPIC and Luo converter with MPPT algorithms", Journal of Information, knowledge, and research in electrical engineering, vol. 03, no. 02, 2013.

10. N. Soumya Smita Raj, B. Urmila "PV fed Zeta converter", International Journal of Engineering Research and Applications, vol. 3, no. 4, July-Aug 2013.n

\section{AUTHORS PROFILE}

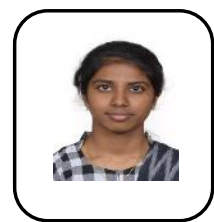

S. Kavyapriya, currently pursuing Master of Engineering in Power Electronics and Drives from Department of Electrical and Electronics Engineering, PSG College of Technology, Coimbatore. Received Bachelor of Engineering in EEE from Department of Electrical and Electronics Engineering, PSG College of Technology, Coimbatore.

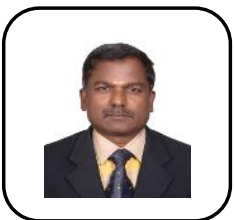

Mr. R. Krishna Kumar, is born in India 1971. He completed his BE (EEE) in 1993 and ME (Power Systems) in 1998. Since 2000 he has been working in EEE Department, PSG College of Technology, Coimbatore-641004. His area of interests include Electrical machines, power systems and control systems. He published about 20 research articles in various national, international conferences and journals. Presently he is doing research on power systems control. 